\title{
Cell-Phone Related Injuries in the United States from 2000-2012
}

\author{
Andreas Saltos \\ Department of Medicine, University of Maryland Medical Center \\ 22 South Greene Street, Baltimore, MD 21201, United States \\ E-mail: asaltos@umm.edu
}

Daniel Smith

Department of Medicine, Georgetown University School of Medicine 3900 Reservoir Road NW, Washington, DC 20007, United States

Email: Daniel.C.Smith@gunet.georgetown.edu

Kristin Schreiber

University of Maryland School of Medicine

22 South Greene Street, Baltimore, MD 21201, United States

E-mail: kristin.schreiber@som.umaryland.edu

Sarah Lichenstein

Department of Nursing, University of Maryland Medical Center

22 South Greene Street, Baltimore, MD 21201, United States

E-mail: slichenstein@umm.edu

Richard Lichenstein (Corresponding author)

Department of Pediatrics, University of Maryland School of Medicine

22 South Greene Street, Baltimore, MD 21201, United States

Tel: 1-410-328-9440 Fax: 1-410-328-0987

E-mail: rlichenstein@peds.umaryland.edu 
Received: April 22, 2015 Accepted: May 14, 2015 Published: May 26, 2015

doi:10.5296/jss.v1i1.7470 URL: http://dx.doi.org/10.5296/jss.v1i1.7470

\begin{abstract}
Background: The incidence of injuries sustained by cell phone users other than drivers has not been adequately researched.

Method: The National Electronic Injury Surveillance (NEISS) database was searched to identify injuries involving cell phone use in all settings other than motor vehicle accidents. The study period was January 2000 to December 2012.

Results: We identified 515 records of Emergency Department (ED) visits related to cell phone use. $48 \%$ of injuries occurred in the home setting. $62 \%$ percent of the patients were female; $55 \%$ were younger than 40 . National estimates, derived from weighted case incidence, revealed statistically significant increases in the number of annual cases, particularly for injuries sustained while texting. Most injuries were minor, but $11 \%$ of patients required hospitalization.
\end{abstract}

Discussion: The estimated national number of injuries associated with cell phone use is increasing annually in all scenarios studied, particularly among pedestrians and while texting.

Conclusion: Distraction is inherent during cell phone use. The injury risk posed by cell phone use must be an integral component of prevention strategies and product design.

Keywords: Cell phones, Distraction, Texting, Injury, Emergency

\title{
1. Introduction
}

The use of cell phones in the United States has increasingly become a part of everyday life. According to a 2013 Pew Research Study, 90\% of Americans own a cell phone (Raine, 2013). In addition, a survey conducted recently by the Centers for Disease Control revealed that nearly half of American households have replaced their use of landline phones with the use of cell phones exclusively (Blumberg, Ganesh, Luke \& Gilbert Gonzales, 2014).

With the increasing prevalence of ownership, cell phone distraction has started to become an increasingly recognized phenomenon. This distraction is thought to occur through two mechanisms: (1) sensory deprivation caused by diverting visual/aural/tactile faculties to interaction with the phone and (2) inattentional blindness caused by decreased cognitive capture of the user's surroundings. Inattentional blindness takes on a increasing role in modern phones as these devices not only provide verbal communication and text messaging but also take photographs, connect to the web, stream music, run games, and send and receive e-mail (Lichenstein, Smith, Ambrose \& Moody, 2012). Inattentional blindness has been studied in drivers but less so in other settings (Drews et al., 2009; Hosking, Young \& Regan, 2009). 
Numerous observational and virtual simulation studies have shown increased risky behavior in pedestrians and drivers interacting with cell phones (Beede \& Kass, 2006; Bungum, Day \& Henry, 2005; Hatfield \& Murphy, 2007; Klauer et al., 2014; Rosenbloom, 2006; Stavrinos, Byington \& Schwebel, 2009; Strayer \& Drew, 2004, 2007; Schwebel at al 2012). However, data are limited regarding national trends in injuries incurred by all cell phone users. Our group and the investigative team led by Nasar (2008) have examined this issue by using the National Electronic Injury Surveillance System (NEISS) database to estimate national annual incidence of injuries sustained by pedestrians while using cell phones (Smith, Schreiber, Saltos, Lichenstein \& Lichenstein, 2013). In this study, we further explore injuries involving cell phone use by including not only pedestrians but also people who were at home or in other indoor settings when the incident occurred. We examine the frequency and types of injuries in these various settings to elucidate incident patterns in order to better understand this emerging health concern.

\section{Methods}

Incident data were obtained from the NEISS database using methodology similar to that employed in our group's previous analysis of pedestrian cell-phone-related injuries (Smith et al, 2013). This database, maintained by the U.S. Consumer Product Safety Commission (CPSC), contains summaries of emergency department (ED) visits for the treatment of injuries related to consumer products. Each year, the NEISS records a random sampling of hospital ED visits in the United States. This sampling can be used to estimate national annual ED visits by using statistical weighting based on the size and hospital region from which the injury was reported (U.S. Consumer Product Safety Commission, 2000). The database was queried for incidents involving product code 0550, "Telephone or telephone accessories," from January 2000 through December 2012.

The initial case list was imported into Microsoft Excel (Redmond, Washington), and cases were randomized using the rand() and sort functions to prevent fatigue bias during review. Cases were then screened to exclude those that involved a landline or fixed telephone, the phone itself causing the injury, or a condition unrelated to distraction (e.g., stroke, chest pain). Screening was performed in two phases: An initial screen to exclude cases was automated using the Microsoft Excel search() feature to identify the key words outlined in Table 1. A second screening was performed by individual review of each case for exclusion using the same criteria outlined above (for cases not easily identified by a keyword or those missed by the automated screening due to spelling or contextual errors [e.g., an ED visit for psychiatric distress triggered by a recent cell phone conversation]).

Table 1. Key Words Used for Exclusion in Initial Automated Screen

\begin{tabular}{lll}
\hline Key Word & No. of Cases Screened & Reason for screening \\
\hline Answer & 1086 & Injury before individual was able to use phone \\
Cord & 849 & Implies corded (not cellular) telephone \\
Reach & 469 & Injury before individual was able to use phone \\
\hline
\end{tabular}


Eye

Pick 200

Drop $\quad 178$

Charger $\quad 136$

Ear $\quad 136$

Syncope $\quad 118$

Throw 91

Mouth $\quad 88$

Threw 88

Antenna $\quad 87$

Chest pain $\quad 70$

Dizzy 46

Swallow $\quad 39$

Receiver $\quad 27$

Telephone pole 21

TIA* 13

Payphone 7

CVA* 6
Implies injury by phone or part as blunt object Injury before individual was able to use phone Implies injury by phone or part as blunt object Accessory rather than cell phone itself Implies injury by phone or part as blunt object Unrelated to distraction by telephone Implies telephone causing injury as a weapon Implies injury by phone or part as blunt object Implies telephone causing injury as a weapon Implies injury by phone or part as blunt object Unrelated to distraction by telephone Unrelated to distraction by telephone Unrelated to distraction by telephone Implies injury by phone or part as blunt object Not related to cell phone use

Unrelated to distraction by telephone

Not related to cell phone use Unrelated to distraction by telephone

* TIA as abbreviation for 'Transient Ischemic Attack' and CVA as abbreviation for 'cerebrovascular accident'

Table 2. Three Criteria for Case Selection in Author Case Review

\begin{tabular}{lll}
\hline \multicolumn{1}{c}{ Criterion } & \multicolumn{1}{c}{ Description of criterion } & \multicolumn{1}{c}{ Examples of excluded cases } \\
\hline Cell phone & $\begin{array}{l}\text { The incident must involve the use of a } \\
\text { cellular/mobile telephone. }\end{array}$ & $\begin{array}{l}\text { Incidents involving land-line } \\
\text { telephones or telephone } \\
\text { accessories }\end{array}$ \\
Distraction & $\begin{array}{l}\text { The cell phone should be used in a } \\
\text { manner capable of providing } \\
\text { distraction (talking into mouthpiece, } \\
\text { texting, reading, or interacting with } \\
\text { device screen or buttons) while } \\
\text { performing another activity. }\end{array}$ & $\begin{array}{l}\text { Incidents involving an injury } \\
\text { caused by a cell phone as a } \\
\text { blunt object (e.g., cell phone } \\
\text { was thrown or dropped), or } \\
\text { injury in an attempt to pick up } \\
\text { or answer phone (e.g., subject } \\
\text { strained back when bending } \\
\text { over) }\end{array}$ \\
& & $\begin{array}{l}\text { Incidents such as stroke, panic } \\
\text { attack, seizure, lightning strike }\end{array}$ \\
Contribution to & $\begin{array}{l}\text { The distraction involved should } \\
\text { reasonably be capable of contributing } \\
\text { to the injury sustained. }\end{array}$ & \\
\hline
\end{tabular}

After these screening processes were completed, the candidate cases were reviewed by each of the five authors. Each incident was rated as a definite, probable, or excluded case based on the 3 criteria presented in Table 2. Definite cases were defined as those that met all criteria 
for inclusion; probable cases were defined as those for which the information necessary to make the determination was incomplete but the information that was available met more than one of the specified criteria. Incidents classified as definite or probable were further categorized by the authors according to setting of the injury (e.g., at home, as a pedestrian, other [bicycling, skateboarding], or unknown) and whether the incident involved texting (defined as text messaging or application use). Of note, incidents involving automobile crashes were excluded because these incidents are generally not included in the NEISS data collection and therefore any estimate based on sporadic cases that made it into the database would vastly underestimate the number of national automobile-related incidents.

Author agreement was calculated using the Cohen's kappa statistic. Kappas were calculated pairwise for each combination of authors, and for each categorization a mean kappa was calculated. Agreement was categorized as 'slight' (kappa $=0-0.2)$, 'fair' (kappa $=0.21-0.4)$, 'moderate' $($ kappa $=0.41-0.60)$, 'good' $($ kappa $=0.61-0.8)$, or 'excellent' $($ kappa $=0.81-1.0)$.

The case identifiers from the final case list were sent to CPSC statisticians, who weighted each incident according to proprietary hospital-specific formulae and estimated annual trends using a restricted maximum likelihood approach. Confidence intervals for each estimate were also derived from the NEISS sampling weights in the reporting hospital. This analysis was performed using a custom Statistical Analysis System (Cary, NC) program. Demographic data (age, sex, month of event) and case characteristics (location of injury, body part injured, type of injury, and disposition) were analyzed using Microsoft Excel for frequencies, and statistical significance was assessed with the $\chi 2$ statistic. Linear regression was performed on estimated annual trends using Microsoft Excel.

Estimates of U.S. national rates of cell phone ownership between May 2000 and September 2013 were calculated for comparison with trends in injury incidence. These estimates were calculated using national population data available from the U.S. Census Bureau and multiplying the population for a given month and year by corresponding rates of cell-phone ownership as reported by the Pew Research Center (U.S. Census Bureau, n.d.; Pew Research Center, 2014).

\section{Results}

A total of 6,341 potential cases occurring between 2000 and 2012 were identified in the NEISS database. After the initial screening (3 536 cases excluded) and the second screening (2 290 cases excluded), 515 cases were selected as probable or definite cell-phone-induced distraction injuries (Figure 1). National annual estimates were derived from these cases, with a conservative estimate including only definite cases and a liberal estimate including both definite and probable cases. 


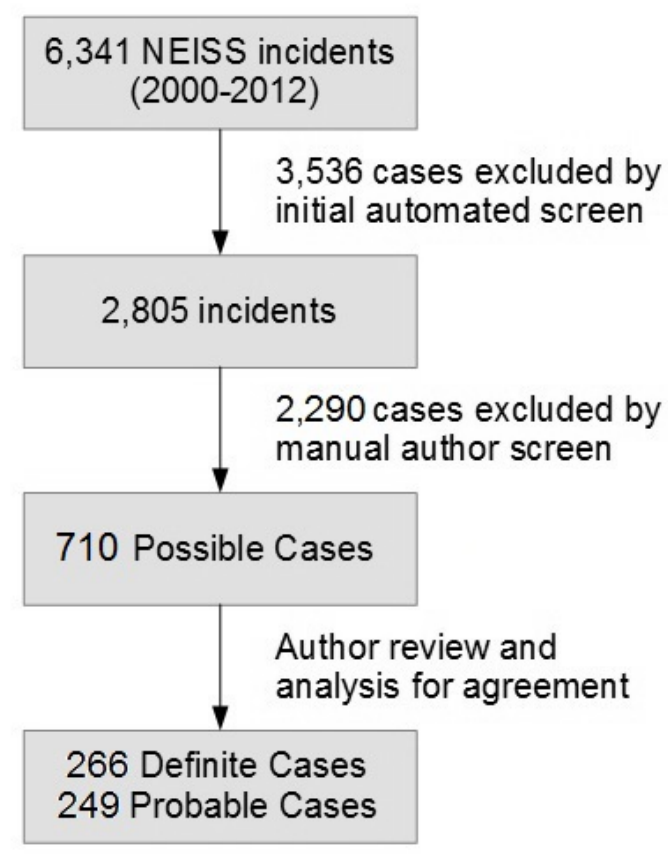

Figure 1. Incident screening results.

Demographic data from the final analyzed cases (definite and probable cases) are shown in Table 3. A majority of cases involved female patients (62\%), and more than half of cases involved patients aged 11 to $40(53 \%)$.

Table 3. Case Demographics $(\mathrm{n}=515)$

\begin{tabular}{|c|c|c|c|c|c|}
\hline Sex & $\begin{array}{l}\text { No. of Cases } \\
(\%)\end{array}$ & Race & $\begin{array}{l}\text { No. of Cases } \\
(\%)\end{array}$ & Age & $\begin{array}{l}\text { No. of Cases } \\
(\%)\end{array}$ \\
\hline Male & $198(38)$ & White & $254(49)$ & 0-10 & $10(2)$ \\
\hline \multirow[t]{8}{*}{ Female } & $317(62)$ & $\begin{array}{l}\text { Black/African } \\
\text { American }\end{array}$ & $90(17)$ & 11-20 & $118(23)$ \\
\hline & & Other & $24(5)$ & 21-30 & 98 (19) \\
\hline & & Not stated in record & $147(29)$ & $31-40$ & $57(11)$ \\
\hline & & & & $41-50$ & $59(11)$ \\
\hline & & & & $51-60$ & $36(7)$ \\
\hline & & & & $61-70$ & $40(8)$ \\
\hline & & & & $\geq 71$ & $96(19)$ \\
\hline & & & & $\begin{array}{l}\text { Not stated in } \\
\text { record }\end{array}$ & $1(0)$ \\
\hline
\end{tabular}


An overview of incident characteristics is shown in Table 4. There was no significant seasonal variation in the cases $(\mathrm{p}=0.20)$. More cases occurred at home $(48 \%)$ or on the street $(11 \%)$ and involved laceration or abrasion injuries $(36 \%)$ or musculoskeletal sprains/strains $(22 \%)$. The majority of patients $(87 \%)$ were discharged from the emergency department, and no fatalities were reported.

Table 4. Incident Characteristics $(\mathrm{n}=515)$

\begin{tabular}{|c|c|c|c|c|c|}
\hline Category & & $\begin{array}{l}\text { No. of Cases } \\
(\%)\end{array}$ & Category & & $\begin{array}{l}\text { No. of Cases } \\
(\%)\end{array}$ \\
\hline \multirow[t]{5}{*}{ Month } & Dec-Feb & $114(22)$ & Injury Type & Dislocation/fracture & $124(24)$ \\
\hline & Mar-May & $139(27)$ & & Laceration/abrasion & $184(36)$ \\
\hline & Jun-Aug & $125(24)$ & & Sprain/strain & $112(22)$ \\
\hline & Sep-Nov & $185(27)$ & & Concussion & $11(2)$ \\
\hline & & & & $\begin{array}{l}\text { Internal organ } \\
\text { injury }\end{array}$ & $34(7)$ \\
\hline \multirow[t]{8}{*}{ Location } & Home & $247(48)$ & & Dental & $0(0)$ \\
\hline & Street/highway & $59(11)$ & & Avulsion/degloving & $1(0)$ \\
\hline & $\begin{array}{l}\text { Other public } \\
\text { property }\end{array}$ & $66(13)$ & & Crushing & $0(0)$ \\
\hline & Industrial place & $0(0)$ & & Hematoma & $2(0)$ \\
\hline & School & $8(2)$ & & Other/unspecified & $47(9)$ \\
\hline & $\begin{array}{l}\text { Place of } \\
\text { recreation/sport }\end{array}$ & $7(1)$ & & & \\
\hline & Not recorded & $128(25)$ & Disposition & Discharged & $446(87)$ \\
\hline & & & & Transferred & $4(1)$ \\
\hline \multirow{6}{*}{$\begin{array}{l}\text { Body Part } \\
\text { Injured }\end{array}$} & Head/face & $146(28)$ & & Admitted & $57(11)$ \\
\hline & Neck & $21(4)$ & & Observation & $1(0)$ \\
\hline & $\begin{array}{l}\text { Upper } \\
\text { extremity }\end{array}$ & $132(26)$ & & $\begin{array}{l}\text { Left prior to being } \\
\text { seen or AMA }\end{array}$ & $6(1)$ \\
\hline & $\begin{array}{l}\text { Lower } \\
\text { extremity }\end{array}$ & $122(24)$ & & Unspecified & $1(0)$ \\
\hline & Trunk & $82(16)$ & & Death & $0(0)$ \\
\hline & Other & $12(2)$ & & & \\
\hline
\end{tabular}




\section{Macrothink

Overall national estimates over time are shown in Figure 2, which demonstrates a significant increasing trend by both conservative $(p<0.0001)$ and liberal estimates $(p=0.0004)$. Although this trend might in part be explained by an increase in cell phone ownership over this time period, the percent growth rate in injury incidence from 2006 to 2012 significantly outpaces the percent growth rate of cell phone ownership. Cell phone ownership grew $4.4 \%$ per year over this period, while injury incidence grew 39\% per year for the liberal estimate $(p=0.002)$ and $135 \%$ per year for the conservative estimate $(p=0.001)$. Figure 3 shows the adjusted annual rate of cell phone injuries (per million cell phone owners), indicating a steady increase $(0.7$ injuries per million cell phone owners per year for both conservative and liberal estimates by linear regression) over the study period.

Overall Cell-Phone Distraction Injuries

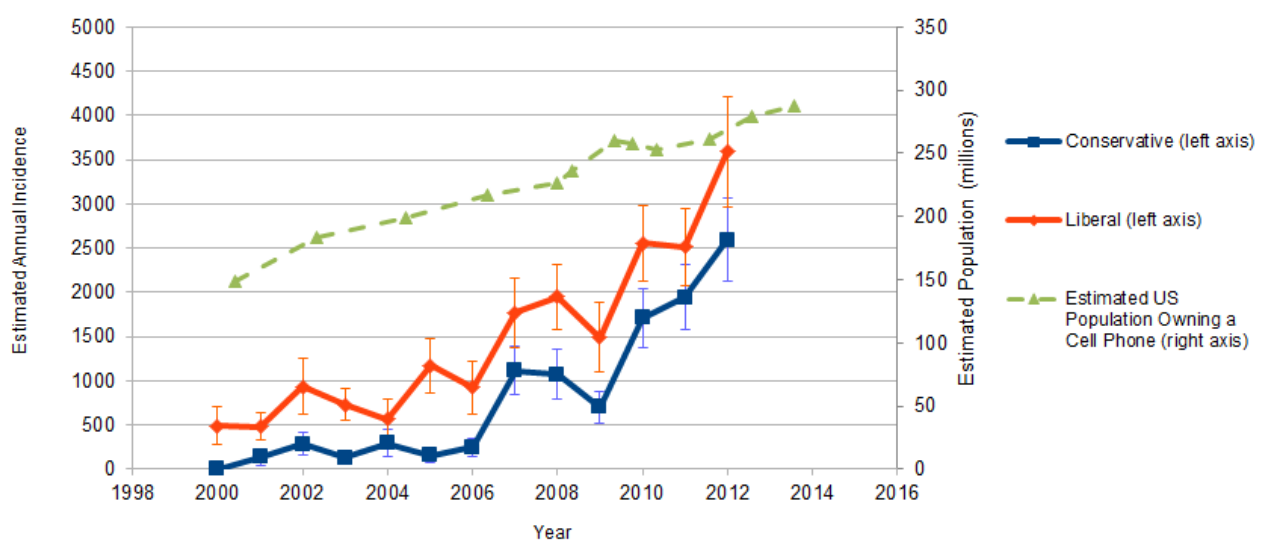

Figure 2. Conservative (definite cases only) and liberal (definite and probable cases) annual estimates of overall cell-phone-related ED visits. Error bars represent one standard deviation from the mean. The dashed line series represents an estimate of US population with cell phone ownership (in millions, measured on the right axis).

Cell-Phone Distraction Injury Rates

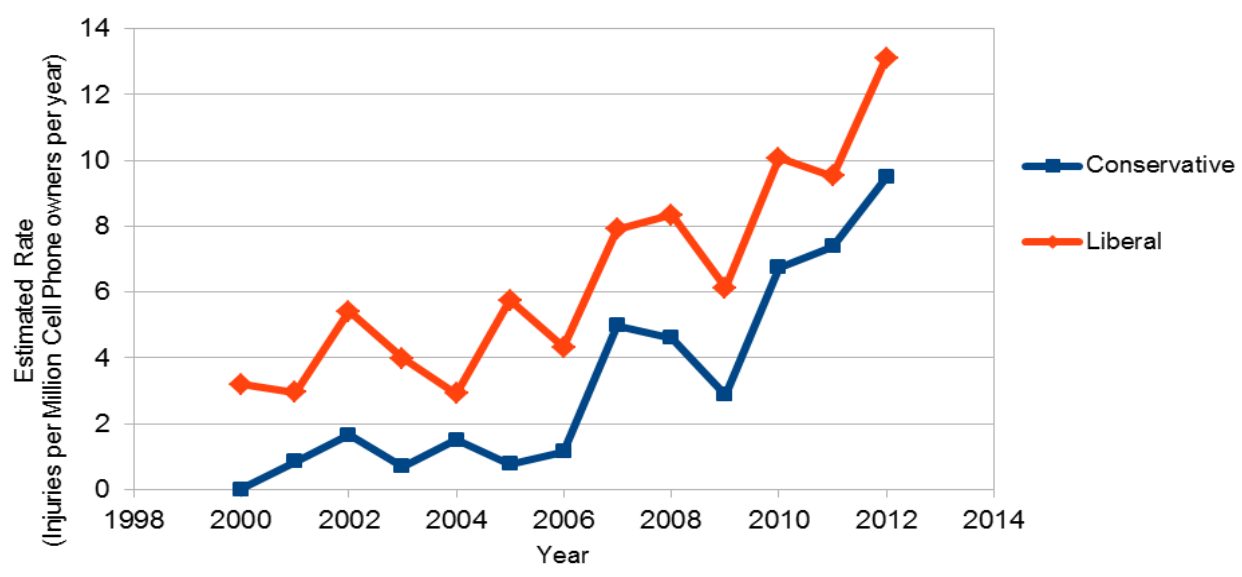

Figure 3. Estimated annual rate of cell phone injuries (per million cell phone owners). Conservative (definite cases only) and liberal (definite and probable cases) estimates are shown. 
Figure 4 shows the estimated national injury cases involving texting, which likewise demonstrate an increasing trend $(\mathrm{p}=0.0354)$. Figure 5 shows the national case number estimates stratified by setting and demonstrates significant increases in number of cases at home and involving pedestrians. Linear regression indicates that the rate of increase in the numbers of cases involving pedestrians (94 cases/year) appears to be greater than the rate of increase for cases occurring at home (50 cases/year).

\section{Incidence of Texting-Related Injuries}

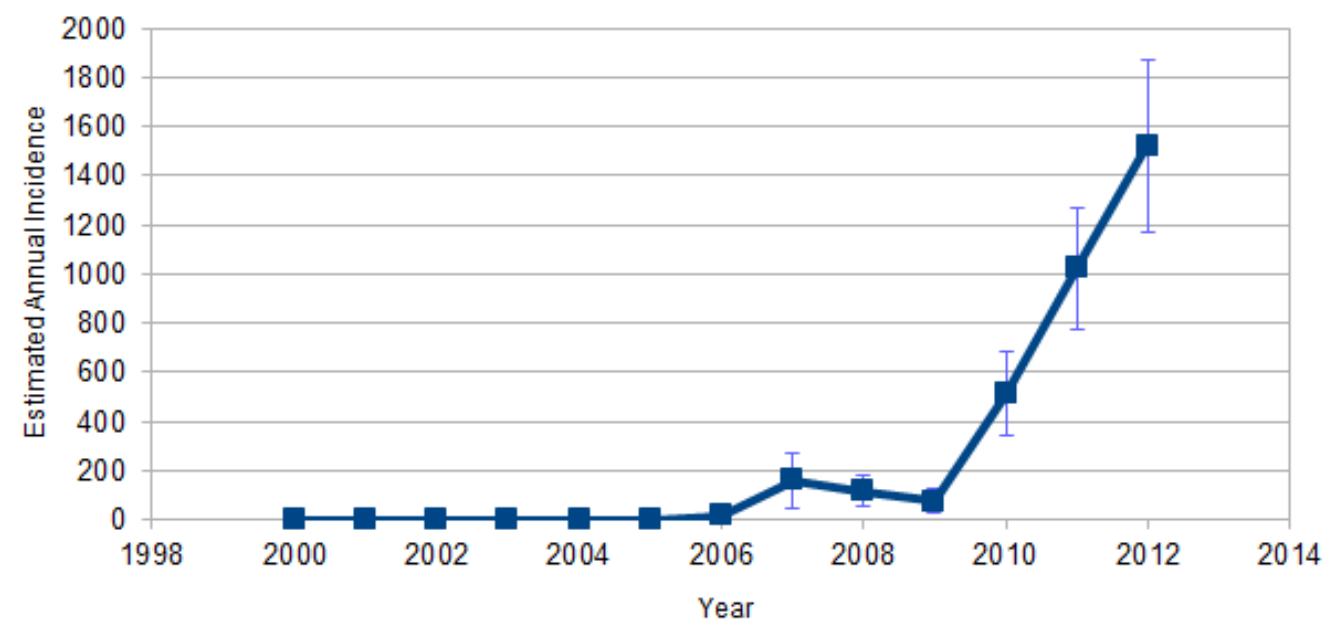

Figure 4. Estimated national texting-related ED visits. Both definite and probable cases are included. Error bars represent one standard deviation from the mean.

Cell-Phone Distraction Injuries by Setting

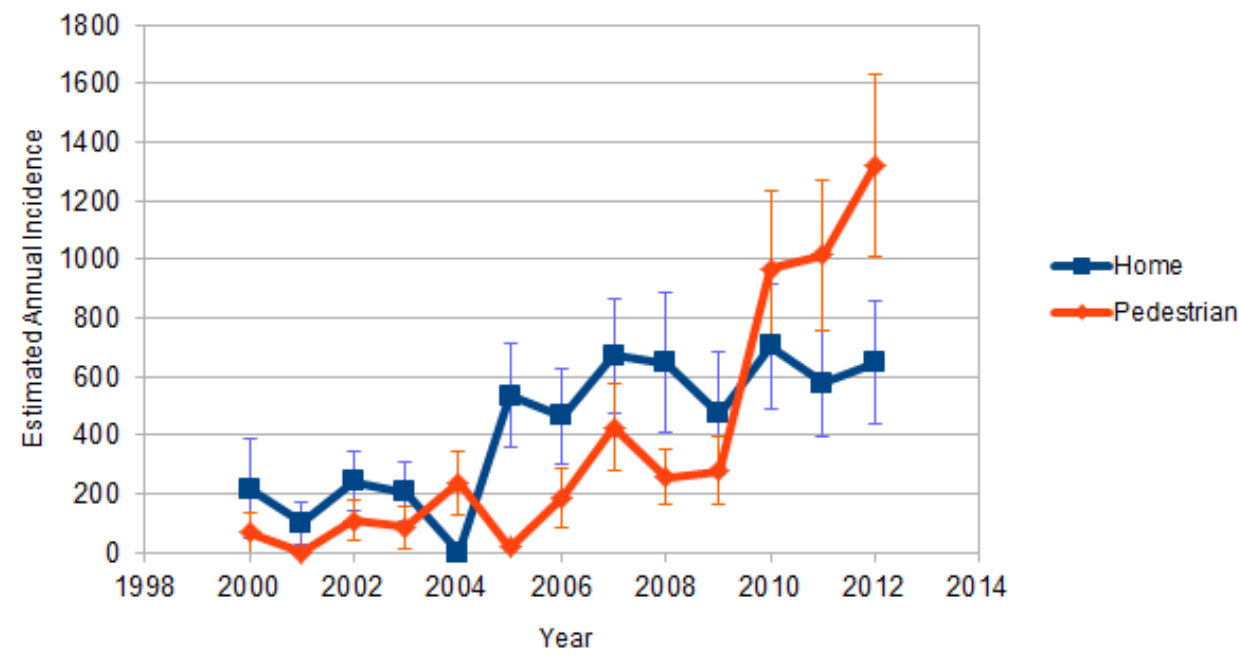

Figure 5. Estimated national cell-phone-related ED visits stratified by setting (either at home or among pedestrians). Both definite and probable cases are included. 


\section{Discussion}

The majority of incidents identified in this study involved people under the age of 40 years, perhaps reflecting the higher rates of cell phone (particularly smartphone) ownership in this group. As found in our previous study, the injured cohort had a predominance of females. This is despite polls suggesting that females are slightly less likely to own cell/smart phones than males. The polls show younger individuals are more likely to use their phone for internet use; moreover women in this age group are more likely than men to use the phone for this purpose, despite having similar overall ownership rates (Madden, Lenhart, Duggan, Cortesi $\&$ Gasser, 2013; Smith, 2013). The difference between genders might also be explained by the increased likelihood of females to seek medical attention after an injury, as observed by Stevens et al in a population of Medicare beneficiaries (2012).

Superficial injuries predominated in the cases reviewed in this study, and the majority of patients were treated in the ED and then sent home. Archival information from news sources indicates that more serious outcomes such as death do occur, but those events would not be captured by the NEISS (Simms, 2013). We categorized the injuries in our study as occurring at home or as a pedestrian but injuries occurred in other settings as well, including while bicycling (40 total cases during the study period). However, these case numbers were too low to allow calculation of statistically meaningful annual estimates. Many cell-phone-related injuries are sustained during automobile crashes; however, as mentioned previously, these cases are not captured through the NEISS database reliably and could not be measured through the methodology of this study.

The incidence of injuries involving cell phone use by pedestrians is growing faster than the incidence among cell phone users at home. This difference might be attributable to the fact that pedestrians are using their cell phones for web browsing, television and other functions, while there are separate appliances for these functions in the home. In addition, prior to the increase in the prevalence of cell phones, cordless telephones were already commonly used in the home. Homeowners with cordless phones have probably become adept at navigating their surroundings while being distracted by phone use. On the other hand, pedestrians are often challenged by new stimuli and more frequent unexpected hazards.

One notable result among our data is the increasing incidence of injuries involving text messaging. Polls show that an increasing number of cell phone users are using their devices for text messaging, as well as applications for email, internet, and other multimedia activities (Duggan, 2013). If the current trend continues, incidents involving text messaging (or other application usage) will soon account for the majority of all injuries related to cell phone use.

An important limitation of our study is that the estimates derived from many of the subcategories created for this study are based on relatively small numbers of cases from the NEISS and are therefore unreliable (U.S. Consumer Product Safety Commission, 2000). Cases were selected by clinicians using strict criteria; no other method was available to validate cases. Using the NEISS, which uses data abstracted from Emergency Department records, may have led to differential reporting. It is possible then that the increasing number of phone-related injuries over time may in part be explained by improved reporting over time. 
Conversely, under-reporting of cases might constitute another limitation, caused by the reluctance of injured cell phone users to report that they were using a phone at the time of the incident, for fear of embarrassment or legal repercussions. Also, busy doctors and nurses may fail to ask or document use of cell phones as an implicating factor during their encounter. Finally, it is impossible to determine the relative contribution of distraction associated with cell phone use in cases involving confounding factors such as intoxication. It is also important to note that the cell phone ownership statistics represented in Figures 2 and 3 are derived using national cell phone ownership estimates that are based on data from US Census Bureau and Pew Research Center, which are entirely separate from the NEISS.

In terms of case selection, author agreement was moderate or better in the majority of categorizations of incidents (Table 5). For the cases identified as "other," agreement was likely low because of a lack of discrete definition for these cases.

Table 5. Author Agreement for Final Case Selection, Using Cohen's Kappa Statistic

\begin{tabular}{lll}
\hline & Mean Kappa & Median Kappa \\
\hline Definite cases & 0.67 & 0.74 \\
Probable cases & 0.78 & 0.78 \\
Home & 0.45 & 0.46 \\
Pedestrian & 0.61 & 0.59 \\
Crossing street & 0.58 & 0.57 \\
Car & 0.81 & 0.81 \\
Bike & 0.94 & 0.95 \\
Other & 0.2 & 0.2 \\
Texting & 0.86 & 0.86 \\
\hline
\end{tabular}

\section{Conclusions}

The number of cell-phone-related ED visits is increasing in parallel with the prevalence of cell phone use in the United States. Many of these injuries are sustained while the user is engaged in text messaging rather than conventional telephone conversation, and this trend appears to have contributed to a sharper increase in the number of incidents in recent years. This trend is observable among users in multiple settings of daily life: while a pedestrian or at home. The majority of these injuries are occurring in younger users (aged 40 and under). Although the injuries typically are not severe, $11 \%$ of our study group required hospitalization.

This study adds to the growing body of evidence correlating cell phone use and risk for injury. To our knowledge, it is the first study to explore and compare cell-phone related distraction injuries in settings other than driving or acting as a pedestrian. Our group previously reported 
on the increasing trend of ambulatory injuries resulting from cell phone distraction (Smith et al., 2013). Our findings in a broader classification of cell phone users reveal similar increasing trends of potential cell-phone-related distraction injury over time.

More research is needed to evaluate for a causal relationship between cell phone use and injury incidence. Research is also necessary to validate efforts designed to reduce the risks of cell-phone-related distraction, including recent legislation passed in various states banning cell phone use while driving and public safety campaigns against text messaging while driving. We hope this study will foster interest in awareness of the risks present in settings other than behind the steering wheel of a car as well as in incorporating safety engineering into future cell phone designs. Wearable devices such as continuous connectivity glasses and armband devices should also be studied for potential beneficial or negative effects toward distraction injuries.

\section{Acknowledgement}

The authors thank Tom Schroeder of the Consumer Product Safety Commission for providing the statistical analysis for this study and Dr. Gordon Smith for his critique and assistance.

The manuscript was copyedited by Linda J. Kesselring, MS, ELS, the technical editor/writer in the Department of Emergency Medicine at the University of Maryland School of Medicine.

\section{References}

Beede, K. E., \& Kass, S. J. (2006). Engrossed in conversation: The impact of cell phones on simulated driving performance. Accident Analysis \& Prevention, 38(2), 415-421. http://dx.doi.org/10.1016/j.aap.2005.10.015

Blumberg, S. J., Ganesh, N., Luke, J. V., \& Gilbert Gonzales, M. H. A. (2014). Wireless substitution: state-level estimates from the National Health Interview Survey, July-December 2013.

Bungum, T. J., Day, C., \& Henry, L. J. (2005). The association of distraction and caution displayed by pedestrians at a lighted crosswalk. Journal of community health, 30(4), 269-279. http://dx.doi.org/10.1007/s10900-005-3705-4

Drews, F. A., Yazdani, H., Godfrey, C. N., Cooper, J. M., \& Strayer, D. L. (2009). Text messaging during simulated driving. Human Factors: The Journal of the Human Factors and Ergonomics Society, 51, 762-770. http://dx.doi.org/10.1177/0018720809353319

Duggan, M. (2013). Cell phone activities - 2013. Pew Research Center: Washington DC. [Online] Retrieved from http://www.pewinternet.org/files/old-media//Files/Reports/2013/PIP _Cell\%20Phone\%20Activities\%20May\%202013.pdf

Hatfield, J., \& Murphy, S. (2007). The effects of mobile phone use on pedestrian crossing behaviour at signalised and unsignalised intersections. Accident Analysis \& Prevention, 39(1), 197-205. http://dx.doi.org/10.1016/j.aap.2006.07.001 
Hosking, S. G., Young, K. L., \& Regan, M. A. (2009). The effects of text messaging on young drivers. Human Factors: The Journal of the Human Factors and Ergonomics Society, 51(4), 582-592. http://dx.doi.org/10.1177/0018720809341575

Klauer, S. G., Guo, F., Simons-Morton, B. G., Ouimet, M. C., Lee, S. E., \& Dingus, T. A. (2014). Distracted driving and risk of road crashes among novice and experienced drivers. New England Journal of Medicine, 370(1), 54-59. http://dx.doi.org/10.1056/nejmsa1204142

Lichenstein, R., Smith, D. C., Ambrose, J. L., \& Moody, L. A. (2012). Headphone use and pedestrian injury and death in the United States: 2004-2011. Injury prevention, 18, 287-290. http://dx.doi.org/10.1136/injuryprev-2011-040161

Madden, M., Lenhart, A., Duggan, M., Cortesi, S., \& Gasser, U. (2013). Teens and technology 2013. Washington, DC: Pew Internet \& American Life Project. [Online] Retrieved from http://www.pewinternet.org/files/old-media/Files/Reports/2013/PIP_Teensand Technology2013.pdf

Nasar, J., Hecht, P., \& Wener, R. (2008). Mobile telephones, distracted attention, and pedestrian safety. Accident Analysis \& Prevention, 40(1), 69-75. http://dx.doi.org/10.1016/j.aap.2007.04.005

Pew Research Center. (2014). Device ownership over time. [Online] Retrieved from www.pewinternet.org/data-trend/mobile/device-ownership/

Raine L. (2013). Cell phone ownership hits 91\% of adults. [Online] Retrieved from www.pewresearch.org/fact-tank/2013/06/06/cell-phone-ownership-hits-91-of-adults

Rosenbloom, T. (2006). Driving performance while using cell phones: an observational study. Journal of Safety Research, 37(2), 207-212. http://dx.doi.org/10.1016/j.jsr.2005.11.007

Schwebel, D. C., Stavrinos, D., Byington, K. W., Davis, T., O’Neal, E. E., \& de Jong, D. (2012). Distraction and pedestrian safety: how talking on the phone, texting, and listening to music impact crossing the street. Accident Analysis \& Prevention, 45, 266-271. http://dx.doi.org/10.1016/j.aap.2011.07.011

Simms, B. (2013, September 11). Man fined in Baltimore county crash that killed 5-year-old boy. WBAL Baltimore. [Online] Retrieved from www.wbaltv.com/news/maryland/baltimorecounty/man-fined-in-baltimore-county-crash-that-killed-5yearold-boy/21871400.

Smith, A. (2013). Smartphone ownership-2013 update. Pew Research Center: Washington DC, 12. [Online] Retrieved from http://www.pewinternet.org/files/old-media/Files/ Reports/2013/PIP_Smartphone_adoption_2013_PDF.pdf

Smith, D. C., Schreiber, K. M., Saltos, A., Lichenstein, S. B., \& Lichenstein, R. (2013). Ambulatory cell phone injuries in the United States: An emerging national concern. Journal of safety research, 47, 19-23. http://dx.doi.org/10.1016/j.jsr.2013.08.003

Stavrinos, D., Byington, K. W., \& Schwebel, D. C. (2009). Effect of cell phone distraction on pediatric pedestrian injury risk. Pediatrics, 123(2), e179-e185. 
http://dx.doi.org/10.1542/peds.2008-1382

Stevens, J. A., Ballesteros, M. F., Mack, K. A., Rudd, R. A., DeCaro, E., \& Adler, G. (2012). Gender differences in seeking care for falls in the aged Medicare Population. American Journal of Preventive Medicine, 43(1), 59-62. http://dx.doi.org/10.1016/j.amepre.2012.03.008

Strayer, D. L., \& Drew, F. A. (2004). Profiles in driver distraction: Effects of cell phone conversations on younger and older drivers. Human Factors: The Journal of the Human Factors and Ergonomics Society, 46(4), 640-649. http://dx.doi.org/10.1518/hfes.46.4. 640.56806

Strayer, D. L., \& Drews, F. A. (2007). Cell-phone-induced driver distraction. Current Directions in Psychological Science, 16(3), 128-131. http://dx.doi.org/10.1111/j.1467-8721.2007.00489.x

U.S. Census Bureau. (n.d.) Population estimates - current estimates data. [Online] Retrieved from www.census.gov/popest/data/

U.S. Consumer Product Safety Commission. (2000). U.S. NEISS, the National Electronic Injury Surveillance System: A tool for researchers. [Online] Retrieved from www.cpsc.gov/neiss/2000d015.pdf

\section{Copyright Disclaimer}

Copyright for this article is retained by the author(s), with first publication rights granted to the journal.

This is an open-access article distributed under the terms and conditions of the Creative Commons Attribution license (http://creativecommons.org/licenses/by/3.0/). 